\title{
KONSTRUKSI PERLINDUNGAN KONSUMEN JASA PENGOBATAN ALTERNATIF (STUDI KASUS DI KOTA SEMARANG)
}

\author{
Ubaidillah Kamal \\ Pengajar di Fakultas Hukum Universitas Negeri Semarang \\ Gedung K Kampus Sekaran Gunungpati Semarang \\ Email : hakam_ubai@yahoo.com
}

\begin{abstract}
Abstrak
Semakin berkembangnya jenis penyakit, penyembuhan secara medis yang tidak selalu menjanjikan kesembuhan dan mengandung resiko, serta keinginan masyarakat untuk dapat sembuh dari penyakitnya secara instan mendorong semakin menjamurnya praktek-praktek jasa pengobatan alternatif di masyarakat termasuk di Kota Semarang. Cara pengobatan dan obat yang digunakan dalam jasa pengobatan alternatif sangat berfariasi dan sering tidak bisa diukur berdasarkan standar-standar medis bahkan banyak yang bersifat "klenik". Banyak kasus menunjukkan jaminan kesembuhan dan garansi bila terjadi hal-hal yang lebih parah bahkan kematian masih jarang diberikan atau ditemukan dalam praktek jasa pengobatan alternatif, bahkan beberapa muncul sebagai kasus pidana penipuan. Tulisan membahas tentang pengaturan Jasa Pengobatan Alternatif di Kota Semarang dan bentuk perlindungan konsumen jasa pengobatan alternatif di Kota Semarang serta tanggung jawab pelaku usaha jasa pengobatan alternatif terhadap konsumennya.

Penelitian ini adalah penelitian kualitatif dengan tipe yuridis-sosiologis. maka pendekatan yang dilakukan adalah pendekatan perundang-undangan (statute approach), pendekatan konsep (conceptual approach), dan pendekatan kasus Teknik pengumpulan data yang digunakan adalah (1) wawancara, (2) observasi, (3)dokumentasi dan (4) tinjauan pustaka. Analisis menggunakan analisis kualitatif.

Pengaturan pengobatan alternatif di Kota Semarang didasarkan kepada peraturan perundangan yang ada, tetapi belum diterapkan secara komprehensif.
\end{abstract}


Bentuk perlindungan kepada konsumen dilakukan secara preventif dan represif bekerjasama antara Dinkes Kota Semarang dengan IKNI, LSM, dan penegak hukum. Ada tiga pola tanggungjawab yang muncul dari pelaku usaha pengobatan alternatif terhadap konsumen, yaitu tanggungjawab etis, tidak bisa memberikan ganti kerugian, dan sengaja tidak mau bertanggungjawab. (4)Kontruksi Perlindungan Konsumen berbasis pembinaan dan pengawasan kepada pelaku usaha agar menjadi dapat diukur, jelas, profesional dan dapat dipertanggungjawabkan sehingga dapat memberikan pelayanan yang terbaik bagi masyarakat sebagai konsumen dengan pelayanan kesehatan yang aman, bermanfaat dan ilmiah.

Kata Kunci: Konstruksi Perlindungan Konsumen, Jasa Pengobatan Alternatif

\section{PENDAHULUAN}

Undang-Undang Dasar 1945 Pasal 28 (h) menyatakan bahwa setiap orang berhak hidup sejahtera lahir dan batin, bertempat tinggal, dan mendapatkan lingkungan hidup yang baik dan sehat serta berhak memperoleh pelayanan kesehatan. Ketentuan tersebut mengatur secara jelas bahwa setiap orang memiliki hak untuk hidup sehat serta mendapatkan pelayanan kesehatan. Upaya memenuhi dan memajukan tingkat kesehatan dilakukan dengan menjamin ketersediaan tenaga kesehatan yang memadai dan merata, tersedia dan semakin meningkatnya fasilitas kesehatan termasuk obat serta kemudahan masyarakat untuk dapat mengakses semua itu.

Ketidakmampuan negara untuk memberikan pelayanan dan jaminan kesehatan yang baik dan terjangkau bagi seluruh warga negara juga menyebabkan masyarakat mencoba jasa pengobatan alternatif. Hal tersebut diperkuat dengan semakin berkembangnya jenis penyakit yang diderita oleh masyarakat dan keinginan masyarakat untuk dapat sembuh dengan cepat dengan cara yang instan. Lebih lagi di kalangan masyarakat Indonesia juga masih mempercayai bahwa sakit yang diderita bukan hanya disebabkan oleh sebab yang biasa tetapi disebabkan oleh hal yang "tidak biasa", sehingga mereka mencari cara-cara penyembuhan yang tidak biasa. 
Bila dikaitkan dengan adanya prinsip partisipatif, maka fasilitas pelayanan kesehatan juga dapat diselenggarakan melalui cara konvensional maupun tradisional. Prinsip partisipatif dalam upaya pelayanan kesehatan dapat dilakukan dengan kuratif yang melibatkan pengobatan konvensional dan tradisional. Pengobatan tersebut bertujuan untuk penyembuhan penyakit, pengurangan penderitaan akibat penyakit, pengendalian penyakit, atau pengendalian kecacatan agar kualitas penderita dapat terjaga seoptimal mungkin

Realitas masyarakat memperlihatkan, pengobatan alternatif dapat bahkan sering digunakan sebagai pilihan lain dalam mengupayakan kesehatan, kesembuhan atau keselamatan seseorang. Tren menunjukkan semakin bertambahnya jumlah, jernis dan cara penyembuhan dengan jasa pengobatan alternatif. Pengobatan alternatif cenderung lebih mengacu pada pengalaman dan ketrampilan yang turun temurun, dengan ramuan bahan obat berasal dari tumbuhan, hewan, mineral dan lain-lain.

Dirjen Bina Kesehatan Masyarakat Depkes menyebutkan, jumlah pengobat tradisional di Indonesia yang tercatat cukup banyak, yaitu 280.000 pengobat tradisional dengan 30 keahlian/spesialisasi. Sejumlah 30.000 jenis tanaman yang ada di Indonesia 950 jenis diantaranya memiliki fungsi penyembuhan yang sudah selayaknya bisa dikembangkan bagi kesejahteraan masyarakat Indonesia. Survei Sosial Ekonomi Nasional tahun 2001, 57,7\% penduduk Indonesia melakukan pengobatan secara medis, 31,7\% menggunakan obat tradisional, dan 9,8\% memilih cara pengobatan tradisional (www.depkes.go.id/seberapa-besar-manfaatpengobatan-alternatif/4-10-2012).

Banyak kasus menunjukkan, bahwa jaminan kesembuhan dan garansi bila terjadi hal-hal yang lebih parah bahkan kematian masih jarang diberikan atau ditemukan dalam praktek jasa pengobatan alternatif, bahkan beberapa muncul sebagai kasus pidana penipuan. Kasus salah obat, salah penanganan, penipuan, pemaksaan, bahkan sampai pencabulan mewarnai dinamika maraknya jasa pengobatan alternatif di Indonesia termasuk juga di Kota Semarang. Ditengarai banyak pasien jasa pengobatan alternatif yang dirugikan tetapi karena ketidak tahuan atau alasan psikologis yang lain mereka tidak berani menyampaikan ke 
pihak yang berwenang. Sehingga kepentingan konsumen sangat potensial untuk dirugikan. Pengaturan secara khusus terhadap jasa pengobatan alternatif serta perlindungan konsumen menjadi hal mendasar yang harus diperhatikan dan diberikan oleh negara.

Kasus Ustad Guntur Bumi "UGB" salah satu jasa pengobatan alternatif yang pernah praktik di Kota Semarang dan kemudian pindah praktik di Jakarta, Kasus Pengobatan alternative Gus Muh di Kawasan Duren Sawit yang dilaporkan ke Polda Metro Jaya (kompas.com), dan beberapa kasus yang lain paling tidak membuka mata kita betapa jasa pengobatan alternatif masih sangat digemari oleh masyarakat walaupun dengan cara dan standar yang tidak jelas. Betapa konsumen banyak yang dirugikan secara psikologis, materi dan kesehatan yang semakin memburuk. Praktik yang diduga banyak melakukan penipuan terhadap konsumen. Dan disisi lain konsumen tidak berdaya untuk menyampaikan pelanggaran atas hak mereka.

Kelalaian yang dilakukan oleh pengobatan alternatif tersebut, tentu saja merugikan "Pasien" yang dalam hal ini disebut sebagai "Konsumen". Pengertian konsumen itu sendiri adalah setiap orang pemakai barang dan/atau jasa yang tersedia dalam masyarakat, baik bagi kepentingan diri sendiri, keluarga, orang lain, maupun makhluk hidup lain dan tidak untuk diperdagangkan (Pasal 1 angka 2 Undang-Undang No.8 Tahun 1999).

Konsumen secara mendasar jelas membutuhkan perlindungan hukum yang bersifat universal. Perlindungan itu dapat kita temukan dalam hukum perlindungan konsumen, karena sifatnya yang internasional sehingga semua orang mempunyai kepentingan yang sama. Mengingat kedudukan konsumen yang relatif lebih lemah dibandingkan dengan kedudukan produsen yang bisa diartikan relatif lebih kuat. Maka pembahasan konsumen akan selalu terasa aktual dan selalu penting untuk dikaji ulang (Kristiyanti 2008:5).

Berkaitan dengan hal-hal tersebut, maka konsumen perlu dilindungi secara hukum dari kemungkinan adanya kerugian yang muncul karena praktik bisnis curang. Berbeda pula dengan kelompok masyarakat sebagai pelaku usaha. Perlindungan yang mereka perlukan adalah bagaimana agar dalam menjalankan 
bisnis tidak disaingi secara tidak wajar, tidak jujur ataupun praktek bisnis lain yang dapat menghambat usaha mereka, perlindungan itu adalah bagi kelangsungan perusahaan (bisnis) dan/atau pendapatan/penghasilan mereka (Nasution 2006:23).

Berdasarkan analisis singkat diatas sangat penting dan strategis untuk melihat kembali bagaimana pengaturan yang dilakukan oleh negara terkait jasa pengobatan alternatif sehingga keberadaannya dapat dirasakan sebagai bagian dari alternatif masyarakat untuk mendapatkan kesembuhan yang mungkin tidak atau belum bisa tertangani secara baik dalam pengobatan "medis" kedokteran, tetapi sekaligus memberikan perlindungan kepada konsumen. Demikian juga terkait dengan bentuk-bentuk tanggungjawab pelaku usaha jasa pengobatan alternatif terhadap konsumen.

Permasalahan yang dikaji adalah (1)Bagaimana pengaturan Jasa Pengobatan Alternatif di Kota Semarang;(2)Bagaimana bentuk perlindungan konsumen jasa pengobatan alternatif di Kota Semarang.;(3)Bagaimanakah tanggung jawab pelaku usaha jasa pengobatan alternatif terhadap konsumennya?

\section{METODE PENELITIAN}

Tipe penelitian yang dilakukan adalah yuridis normatif-empiris dengan pertimbangan bahwa tolak penelitian ini akan menganalisis peraturan perundangundangan dan kebijakan lainnya terkait dengan pengaturan jasa pengobatan alternatif dan bentuk-bentuk perlindungan konsumen jasa pengobatan alternatif ini.

Sehubungan dengan tipe penelitian yang digunakan yakni kombinasi normatif-empiris, maka pendekatan yang dilakukan adalah pendekatan perundang-undangan (statute approach), pendekatan konsep (conceptual approach), dan pendekatan kasus (Marzuki, 2005 dan Ibrahim, 2005). pendekatan kasus digunakan untuk mengkaji penerapan norma-norma atau kaidah hukum yang mengatur jasa pengobatan alternatif dan perlindungan konsumen. Data yang diambil dalam penelitian ini adalah data primer dan data sekunder.

Data yang dihasilkan dari lapangan baik data primer maupun data sekunder terlebih dahulu diorganisasikan ke dalam suatu pola, kategori, dan satuan uraian 
dasar. Kemudian data tersebut dianalisis secara deskriptif kualitatif, sehingga ditemukan hubungan diantara dimensi-dimensi yang menjadi pertanyaan dalam penelitian ini (Moleong, 2001). Analisa data yang dipergunakan adalah analisa kualitatif dengan model interaktif (Interctiv Model Analysis).

\section{HASIL DAN PEMBAHASAN}

Kota Semarang sebagai wilayah penelitian secara geografis memiliki luas $373,70 \mathrm{Km}^{2}$ dan secara administratif Kota Semarang terbagi menjadi 16 Kecamatan dan 177 Kelurahan dengan jumlah penduduk menurut Profil Kependudukan Kota Semarang oleh BPS sampai dengan akhir Desember tahun 2016 sebesar 1.765.396 jiwa, yang terdiridari 880.257 jiwa penduduk laki-laki dan 885.139 jiwa penduduk perempuan.

Pemerintah sangat memperhatikan dan berupaya meningkatkan kesehatan masyarakat dengan alasan kemanusiaan, dan karena keuntungan positif dari kesehatan baik bagi individu masyarakat maupun untuk tujuan lain yang diinginkan masyarakat. Usaha tersebut dilakukan dengan berbagai progam baik yang sifatnya promotif, preventif maupun kuratif antara lain melalui pendidikan kesehatan, imunisasi, pemberantasan penyakit menular, penyediaan air bersih dan sanitasi, dan pelayanan kesehatan (Indikator Kesejahteraan Rakyat Kota Semarang Tahun 2010: 18).

Fasilitas kesehatan tertinggi di Kota Semarang adalah praktek dokter/poliklinik yang mencapai 52,5\%, berikutnya adalah puskesmas yang mencapai 31,4 \% dan rumah sakit dengan sekitar 13,6\% (Statistik Kota Semarang 2011). Berikut adalah tabel banyaknya sarana dan prasarana kesehatan di Kota Semarang untuk tahun 2015-2016:

Tabel 1: Jumlah Sarana dan Prasarana Kesehatan

\begin{tabular}{|l|l|l|l|}
\hline \multirow{2}{*}{ No } & \multirow{2}{*}{ Sarana dan Prasarana } & \multicolumn{2}{|c|}{ Tahun } \\
\cline { 3 - 4 } & & 2015 & 2016 \\
\hline \hline 1 & Rumah Sakit Umum: & & \\
\hline & a. Rumah Sakit Swasta & 10 & 10 \\
\hline & Rumah Sakit Umum Daerah & 2 & 2 \\
\hline & Rumah Sakit Umum Pusat & 1 & 1 \\
\hline
\end{tabular}




\begin{tabular}{|c|c|c|c|}
\hline & $\begin{array}{c}\text { d. Rumah Sakit Umum } \\
\text { TNI/POLRI }\end{array}$ & 3 & 3 \\
\hline & e. Rumah Sakit Khusus & 9 & 9 \\
\hline 2. & Rumah Sakit Bersalin/BKIA & 6 & 6 \\
\hline 3. & Puskesmas & 37 & 37 \\
\hline 4. & Puskesmas Pembantu & 34 & 34 \\
\hline 5. & Puskesmas Keliling & 37 & 37 \\
\hline 6. & Posyandu yang ada & 1.529 & 1.533 \\
\hline 7. & Posyandu yang aktif & 1.529 & 1.055 \\
\hline 8. & Apotik & 369 & - \\
\hline 9. & Lab. Kesehatan Swasta & 30 & - \\
\hline 10. & Klinik Spesialis & 14 & - \\
\hline 11. & Optik & 90 & 95 \\
\hline 12. & Klinik 24 jam & 9 & 13 \\
\hline 13. & Toko Obat & 65 & 20 \\
\hline 14. & BP Umum & 159 & 139 \\
\hline 15. & BP Gigi & 8 & 24 \\
\hline 16. & PBDS/Klinik Utama & 7 & 23 \\
\hline 17. & $\begin{array}{c}\text { Dokter Umum Praktek } \\
\text { Swasta }\end{array}$ & 1.176 & 1.327 \\
\hline 18. & Dokter Spesialis Swasta & 649 & 645 \\
\hline 19. & Dokter Gigi Swasta & 294 & 328 \\
\hline 20. & Bidan Praktek Swasta & 50 & 323 \\
\hline
\end{tabular}

Sumber: Profil Kesehatan Kota Semarang 2011

Jumlah sarana dan prasarana diatas jika dinilai dari Neath Death Rate $(N D R)$ atau mutu pelayanan/perawatan di rumah sakit, pencapaian NDR di KotaSemarang pada tahun 2016 sebesar 16,6 permil, mengalami penurunan jikadibandingkan tahun 2015 yang sebesar 24,8 permil dengan demikian secarakeseluruhan pelayanan rumah sakit di Kota Semarang masih tergolong baik (Profil Dinas Kesehatan Kota Senarang 2016). Persebaran fisik tersebut diakui pula belum diikuti sepenuhnya dengan peningkatan mutu pelayanan (Rencana dan Strategi Dinkes Kota Semarang 2010-1015). Peningkatan sumber daya manusia 
(SDM) dibidang kesehatan sangat diperlukan, agar mampu bekerja secara profesional sehingga dapat mengembangkan kemampuannya dalam rangka mewujudkan pelayanan kesehatan yang optimal pada masyarakat.

Profil pengobat tradisional tahun 2015 di Kota Semarang menjelaskan terdapat beberapa jenis pengobatan alternatif Berikut adalah tabel jumlah pengobatan alternatif/tradisional di Kota Semarang untuk tahun 2015:

Tabel 2 : Jumlah Pengobatan Tradisional Kota Semarang

\begin{tabular}{|c|c|c|c|}
\hline \multirow[b]{2}{*}{ No. } & \multicolumn{2}{|c|}{ Jenis Pengobatan Alternatif } & \multirow[t]{2}{*}{ Jumlah } \\
\hline & Ketrampilan & Ramuan & \\
\hline 1. & Dukun Bayi & & 18 \\
\hline 2. & Ceragem & & 8 \\
\hline 3. & Salon & & 6 \\
\hline 4. & Pijat Urut & & 31 \\
\hline 5. & Paranormal & & 3 \\
\hline 6. & Alternatif & & 2 \\
\hline 7. & Alternatif Pijat/Pijat & & 42 \\
\hline 8. & Pijat Terapi & & 1 \\
\hline 9. & Pijat Bayi & & 3 \\
\hline 10. & & Jamu/Jamu Gendong & 34 \\
\hline 11. & Akupuntur/Tusuk Jarum & & 20 \\
\hline 12. & & Shinse & 3 \\
\hline 13. & Pijat Refleksi & & 2 \\
\hline 14. & Shiatu & & 7 \\
\hline 15. & & Aromaterapis & 2 \\
\hline 16. & Bekam & & 3 \\
\hline 17. & Message & & 3 \\
\hline 18. & Sangkal Putung & & 2 \\
\hline 19. & Sunat & & 7 \\
\hline 20. & Gurah & & 1 \\
\hline
\end{tabular}




\section{Pengaturan Jasa Pengobatan Alternatif di Kota Semarang}

Pemerintah telah menerbitkan Peraturan Menteri Kesehatan RI Nomor 1109 Tahun 2007 tentang penyelenggaraan pengobatan komplementer-alternatif di fasilitas pelayanan kesehatan. Menurut aturan itu, pelayanan komplementeralternatif dapat dilaksanakan secara sinergi, terintegrasi, dan mandiri di fasilitas pelayanan kesehatan. Pengobatan itu harus aman, bermanfaat, bermutu, dan dikaji institusi berwenang sesuai dengan ketentuan berlaku.

Selain itu, dalam Permenkes RI No 1186/Menkes/Per/XI/1996 diatur tentang pemanfaatan akupunktur di sarana pelayanan kesehatan. Di dalam salah satu pasal dari Permenkes tersebut menyebutkan bahwa pengobatan tradisional akupunktur dapat dilaksanakan dan diterapkan pada sarana pelayanan kesehatan sebagai pengobatan alternatif di samping pelayanan kesehatan pada umumnya.

Sementara itu, Keputusan Menkes RI No 1076/Menkes/SK/VII/2003 mengatur tentang penyelenggaraan Pengobatan Tradisional. Di dalam peraturan tersebut diuraikan cara- cara mendapatkan izin praktek pengobatan tradisional beserta syarat- syaratnya. Khusus untuk obat herbal, pemerintah mengeluarkan Keputusan Menkes RI Nomor 121 Tahun 2008 tentang Standar Pelayanan Medik Herbal. Untuk terapi SPA (Solus Per Aqua) atau dalam bahasa Indonesia sering diartikan sebagai terapi Sehat Pakai Air, diatur dalam Permenkes RI No. 1205/ Menkes/Per/X/2004 tentang pedoman persyaratan kesehatan pelayanan Sehat Pakai Air (SPA).

Saat ini, pengawasan pada penyelenggaraan praktik terapi komplementer di masyarakat baru berupa pendaftaran saja oleh pemerintah daerah. Bahkan, dari hasil penelusuran terbaru oleh dinas kesehatan di berbagai daerah, banyak sarana/tenaga terapi komplementer tidak terdaftar di dinas kesehatan setempat, sehingga hal ini sangat dikhawatirkan banyak merebak pengobatan palsu yang berkedok terapi kompelementer/ alternatif yang dijalankan oleh tenaga yang tidak berkompeten, yang pada akhirnya dapat membahayakan masyarakat.

Legalisasi Pengobatan tradisional Pengobatan tradisional dapat berperan sebagai salah satu bentuk kebijakan pemerintah daerah yang berbasis kearifan lokal demi terciptanya kesejahteraan masyarakat. Dalam pelaksanaan kebijakan 
pelayanan kesehatan melalui pengobatan tradisional, pemerintah daerah juga harus menyusun regulasi yang relevan dengan konteks kebijakan tersebut demi terwujudnya kesejahteraan masyarakat di daerahnya. Penyelenggaraan kebijakan pelayanan kesehatan melalui pengobatan tradisional juga harus mempunyai dasar hukum di setiap tingkatan yang menjamin terwujudnya asas kepastian, keadilan dan juga kemanfaatan.

Penyelenggaraan dari pengobatan tradisional dimulai dari perizinan. Sebagai pelaksanaan dari hal tersebut, seluruh pengobat tradisional di Indonesia harus melampaui beberapa tahapan untuk mendapatkan pengakuan dan legalisasi dari pemerintah. Tahap pertama adalah melalui perizinan yang berfungsi untuk memperoleh Surat Terdaftar Pengobat Tradisional dengan cara mendaftarkan dirinya ke Kepala Dinas Kesehatan Kabupaten/Kota. Surat Terdaftar Pengobat Tradisional yang selanjutnya disebut STPT adalah bukti tertulis yang diberikan kepada pengobat tradisional yang telah melaksanakan pendaftaran. STPT dikeluarkan oleh Kepala Dinas Kesehatan Kabupaten/Kota selambat-lambatnya satu bulan setelah permohonan dan seluruh kelengkapan dipenuhi.

Setelah pengobat tradisional memiliki STPT, pengobat tradisonal dapat diberikan Surat Izin Pengobat Tradisional. Surat Izin Pengobat Tradisional (SIPT) adalah bukti tertulis yang diberikan kepada pengobat tradisional yang metodenya telah dikaji, diteliti dan diuji terbukti aman dan bermanfaat bagi kesehatan.

Keberadaan pasal tersebut secara tidak langsung pemerintah melarang pendirian usaha dibidang pelayanan jasa atau pengobatan altermatif tanpa seizin dari pemerintah atau dalam hal pengobatan alternatif tanpa seizin Dinas Kesehatan dan rekomendasi dari IKNI (Ikatan Neuropati Indonesia). Seperti perkatakan Bp. Tjandra Wijaja selaku Direktur dari IKNI yang mengatakan jika ditemukannya pengobatan alternatif yang tidak berizin membuktikan jika kesadaran pelaku usaha untuk mendaftarkan usahanya masih kurang padahal dengan izin pelaku usaha akan lebih mendapatkan pembinaan dan pengawasan untuk kegiatan usahanya. Ikatan Neuropati Indonesia juga memberikan pelatihan kepada masyarakat yang tertarik pada pengobatan tradisional, dengan pelatihan 
tersebut masyarakat dapat secara langsung mendapat rekomendasi untuk membuka usaha praktik pengobatan tradisional secara pribadi.

\section{Bentuk Perlindungan Konsumen Jasa Pengobatan Alternatif di Kota Semarang}

Bentuk perlindungan konsumen pengguna jasa pengobatan alternatif di Kota Semarang terdiri dari banyak ragam dan penanganannya. Pihak yang bertanggungjawab langsung adalah Dinas Kesehatan Kota Semarang yang dalam pelaksanaannya dibantu oleh instansi, badan, organisasi, Lembaga Swadaya Masyarakat serta anggota masyarakat itu sendiri.

Dinas Kesehatan dan IKNI memberikan penjelasan, jika memang ditemukan pengobatan sangkal putungyang melakukan malpraktek itu seatau kelalaian, pasien dapat melaporkannya pada Dinas Kesehatan, kemudian DINKES bersama IKNI akan melakukan sidak langsung ke pengobatan alternatif tersebut dan langsung menanyakan pada pengobatnya. Hal tersebut juga tidak secara langsung memberikan jaminan jika pengobatan alternatif tersebut akan memenuhi tanggung jawabnya sebagai pelaku usaha yang merugikan konsumen. Direktur IKNI Bapak Tjandra Widjaja juga mengatakan jika ada yang merasa dirinya menjadi korban malpraktek atau kelalaian pengobat alternatif dapat melaporkan langsung ke Kepolisian.

Kenyataan tersebut menunjukkan bahwa ada upaya perlidungan kepada konsumen jasa pengobatan alternatif yang dilakukan oleh Dinas Kesehatan dan IKNI, bahkan termasuk laporan langsung ke kepolisian jika dianggap telah terjadi mal praktek. Bentuk Perlindungan kepada konsumen jasa pengobatan alternatif juga dilakukan dengan cara : (1) Pemberlakuan Peraturan Perundang-undangan yang berlaku tentang pengobatan tradisional/pengobatan alternatif; (2) Pembentukan dan Peran serta IKNI (Ikatan Neuropati Indonesia) di Kota Semarang; (3) Pembentukan dan pengoptimalan Sentra Pengembangan dan Penerapan Pengobatan Tradisional (P3T), Balai Kesehatan Tradisional Masyarakat (BKTM) dan Loka Kesehatan Tradisional Masyarakat (LKTM); (4) Pembinaan, pengawasan dan Sosialisasi Dinkes kepada pelaku usaha pengobatan alternatif.dan Konsumen; (5) Upaya dan Anjuran penyusunan SOP (Standar 
Operational Procedure) bagi masing-masing jasa pengobatan alternatif; (6) Pemberdayaan lembaga perlindungan konsumen swadaya masyarakat (LPKSM). dan Badan Penyelesaian Sengketa Konsumen (BPSK).

\section{Tanggungjawab Pelaku Usaha Pengobatan Alternatif}

Pelaku usaha dengan mudah berkelit dan lepas dari jerat hukum. Adanya tanggung jawab yang dibebankan pada pelaku usaha, diharapkan pelaku usaha lebih berhati-hati dan lebih optimal dalam melakukan produksi dan pengawasan produksi barang/jasanya agar tetap menguntungkan pihak konsumen maupun pelaku usaha itu sendiri. Tanggung jawab produk dalam penelitian ini terfokus pada tanggung jawab pelaku usaha pengobatan alternatif atas pengaduan dari pengguna jasa usaha tersebut.

Dinas kesehatan sebagai badan yang berwenang mengatasi masalah kesehatan juga mengatakan jika sebagai besar pengobatan tradisional tidak dapat memberikan ganti rugi atas pengobatannya karena proses pembuktiannya yang sulit.

Hasil penelitian ditemukan jika memang belum ada standar untuk tata cara dan/atau ilmu yang ditetapkan oleh pemerintah atau setidaknya batasan dari cara yang boleh dan tidak boleh dilakukan oleh pengobat. Keselamatan pasien sebagai konsumen dari pengobatan sangkal putung disini belum dijamin sepenuhnya karena bisa saja apa yang dilakukan oleh pengobat melukai atau bahkan sampai menyakiti pasien.

Kelalaian terjadi akibat suatu tindakan yang tanpa diduga dan disengaja oleh seseorang. Tentu saja tidak hanya dokter yang memiliki kode etik yang harus bertanggung jawab atas malpraktek atau kelalaian, pengobat alternatif sebagai pelaku usaha juga berkewajiban terhadap hal tersebut.

Sebagian besar para pelaku usaha tidak memberikan informasi yang jelas tentang tindakan pengobatan yang mereka lakukan, ketika pasien datang mereka langsung melakukan proses pengobatan. Padahal kewajiban tersebut seperti yang sudah dijelaskan diatas tidak hanya dinyatakan pada Pasal 8 Undang-Undang Nomor 36 Tahun 2009 tentang Kesehatan namun juga tercantum pada SK Menteri Kesehatan RI No. 1076/MENKES/SK/VII/2003 
Hal tersebut juga tidak secara langsung memberikan jaminan jika pengobatan alternatif tersebut akan memenuhi tanggung jawabnya sebagai pelaku usaha yang merugikan konsumen. Direktur IKNI Bapak Tjandra Widjaja juga mengatakan jika ada yang merasa dirinya menjadi korban malpraktek atau kelalaian pengobat alternatif dapat melaporkan langsung ke Kepolisian.

Ketidakjelasan pelaksanaan tanggung jawab para pengobat alternatif disini dapat sangat merugikan konsumen. Konsumen sebagai pihak yang lemah disini pun juga tidak mendapatkan kejelasan dan kepastian, pihak-pihak yang terkait mungkin memberikan solusi namun banyak juga dari solusi tersebut yang tidak jelas ujungnya. Kewajiban pelaku usaha untuk memberikan jaminan kepada konsumen jelas dikatakan Pasal 26 Undang-Undang Nomor 8 Tahun 1999 tentang Perlindungan Konsumen sebagai berikut: “ Pelaku usaha yang memperdagangkan jasa wajib memenuhi jaminan dan/atau garansi yang disepakati dan/atau yang diperjanjiakan ".

Pelaku usaha bisa jadi harus bertanggung jawab secara hukum, yang sering terjadi pelaku usaha dengan mudah berkelit dan lepas dari jerat hukum. Tanggung jawab produk yang dibebankan pada pelaku usaha, diharapkan pelaku usaha lebih berhati-hati dan akan optimal dalam melakukan produksi dan pengawasan produksi barang/jasanya agar tetap menguntungkan pihak konsumen maupun pelaku usaha itu sendiri. Pemerintah sebagai pihak yang juga memiliki peranan penting dalam upaya penyelenggaraan pelayanan kesehatan yang bermutu seharusnya lebih aktif dalam melakukan pembinaan dan pengawasan terhadap perkembangan pengobatan alternatif..

Tanggungjawab yang muncul sebagian besar adalah tanggungjawab etis atau moral dari pelaku usaha jasa pengobatan alternatif, atas dorongan benarbenar ingin membantu kesembuhan pasien dengan keterampilan atau obat yang dimiliki, sehingga bila belum ada kesembuhan atau keluhan makan akan diusahakan kembali. Masyarakat cenderung jarang yang melakukan upaya tuntutan, gugatan atau sejenisnya, karena ada hubungan unik antara pengobat dan pasien pengobatan alternatif yaitu hubungan "kemakluman". Ada perasaan "Sembuh berarti jodoh, nggak sembuh berarti belum jodoh". 


\section{Konstruksi Perlindungan Konsumen Pengobatan Alternatif di Kota Semarang}

Struktur, pola atau sistem dalam perlindungan konsumen secara umum masih mendasarkan diri kepada hak dan kewajiban pelaku usaha dan konsumen. Sehingga perlu dibangun sebuah konstruksi baru perlindungan konsumen yang tidak hanya mendasarkan diri kepada hak dan kewajiban mereka tetapi juga berbasis kepada pembinaan dan pengawasan yang baik kepada pelaku usaha. Dalam hal ini adalah Pelaku Usaha Jasa Pengobatan alternatif. Oleh pemerintah daerah dapat dijelaskan dengan diagram berikut ini.

Skema 1 : Konstruksi Perlindungan Konsumen Berbasis Pembinaan dan Pengawasan Pelaku Usaha Jasa Pengobatan Alternatif

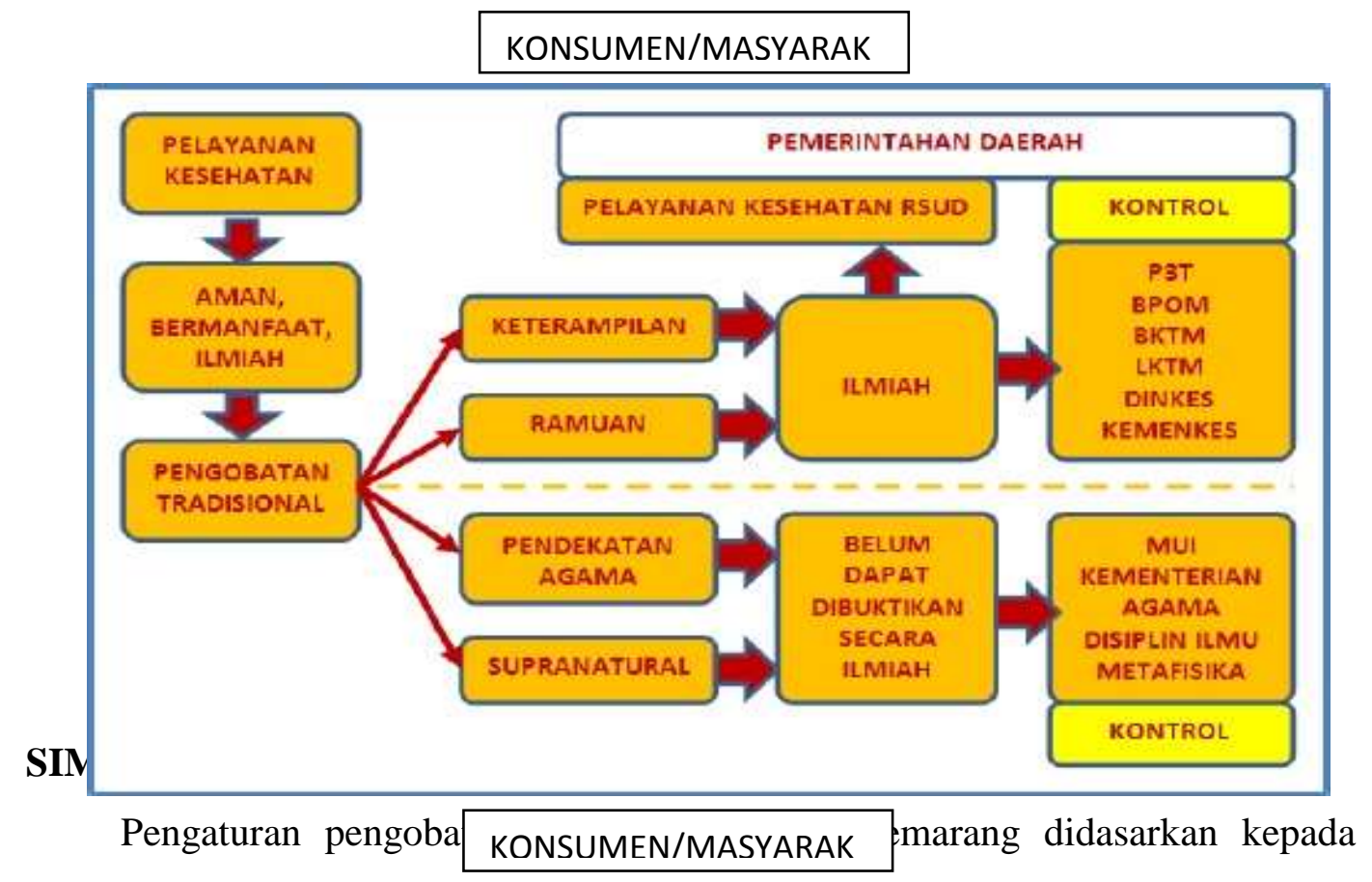

peraturan perundangan yang ada, tetapi belum diterapkan secara komprehensif. Bentuk perlindungan kepada konsumen dilakukan secara preventif dan represif bekerjasama antara Dinkes Kota Semarang dengan IKNI, LSM, dan penegak hukum. Ada tiga pola tanggungjawab yang muncul dari pelaku usaha pengobatan alternatif terhadap konsumen, yaitu tanggungjawab etis, tidak bisa memberikan ganti kerugian, dan sengaja tidak mau bertanggungjawab. Kontruksi Perlindungan Konsumen berbasis upaya pengawasan dan pembinaan kepada pelaku usaha pengobatan alternative agar menjadi terukur, jelas, profesional dan dapat 
dipertanggungjawabkan sehingga dapat memberikan pelayanan yang terbaik bagi masyarakat sebagai konsumen dengan pelayanan kesehatan yang aman, bermanfaat dan ilmiah. Sehingga pengobatan alternative bergerak menjadi mitra Negara untuk mewujudkan jaminan kesehatan aman, bermanfaat, ilmiah dan terjangkau menuju Indonesia Sehat 2020.

Kepada pemerintah Kota Semarang agar membentuk satu unit tersendiri di struktur dinas khusus untuk membina, mengelola dan mengawasi praktek pelaku usaha jasa pengobatan alternatif, memberikan sanksi yang tegas, memberikan penyuluhan kepada konsumen melalui berbagai media tentang tentang prkatik yang terdaftar dan tidak terdaftar dan mengenai konsumen cerdas. Kepada masyarakat/konsumen agar senantiasa cermat memilih atau menggunakan jasa pengobatn alternatif dengan semua jenisnya. Apabila terjadi hal yang dianggap merugikan, malpraktek atau penipuan langsung menyampaikannya kepada dinas kesehatan, lembaga perlindungan konsumen atau kepolisian secara langsung.

\section{DAFTAR PUSTAKA}

Amirudin dan H. Z. Asikin. 2004. Pengantar Metode Penelitian Hukum. Jakarta: Raja Grafindo Persada.

Bungin, Burhan. 2001. Metodologi Penelitian Sosial : Format-Format Kantitatif dan Kualitatif. Surabaya: Airlangga University Press

Brannen, Julia.1997. Memadu Metode Penelitian Kualitatif dan Kuantitatif. Terjemahan Nuktah Arfawie Kurde,dkk. Yogyakarta: Pustaka Pelajar.

Kristiyanti, C. T. S. 2008. Hukum Perlindungan Konsumen. Jakarta: Sinar Grafika

Miru, A. dan S. Yodo. 2010. Hukum Perlindungan Konsumen. Jakarta: Raja Grafindo Persada.

Milles, Mattew dan Huberman, Michael. 1992. Analisis Data Kualitatif.Jakarta: Universitas Indonesia.

Moleong, L.J. 2007. Metodologi Penelitian Kualitatif. Bandung: Remaja Rosdakarya. 
Nasution, Az. 2006. Hukum Perlindungan Konsumen. Jakarta: Diadit Media.

Rajaguguk, Erman, dkk. 2000. Hukum Perlindungan Konsumen. Bandung Mandar Maju.

Samsunjaya, Sagita. 2007. Mengenal Pengobatan Modern dan Pengobatan Alternatif. Jakarta: CV. Visindo Media Persada.

Sarwono, J. 2006. Metode Penelitian Kuantitatif dan Kualitatif. Yogyakarta: Graha Ilmu.

Shidarta. 2000. Hukum Perlindungan Konsumen. Jakarta: Grasindo.

Sidabalok, J. 2006. Hukum Perlindungan Konsumen di Indonesia. Bandung: PT. Citra Aditya Bakti.

\section{Peraturan Perundang-undangan :}

Undang-Undang Perlindungan Konsumen Nomor 8 Tahun 1999.

Undang-Undang Nomor 36 Tahun 2009 Tentang Kesehatan.

SK Menteri Kesehatan RI No.1076/Menkes/SK/VII/2003 tentang Penyelenggaraan Pengobatan Tradisional (BATRA) . 